\title{
Esophageal Leiomyoma and Simultaneous Overlying Squamous Cell Carcinoma: A Case Report and Review of the Literature
}

Saadat Mehrabi

Yasuj University of Medical Sciences

Mohammad Javad Yavari Barhaghtalab ( $\nabla$ mj.yavari.barhaghtalab@yums.ac.ir)

Yasuj University of Medical Sciences https://orcid.org/0000-0002-2859-044X

Safoora Hejazinia

Yasuj University of Medical Sciences

Hossein Saedi

Yasuj University of Medical Sciences

\section{Case report}

Keywords: Esophageal squamous cell carcinoma, Leiomyoma of esophagus, simultaneous occurrence, overlying, esophageal resection

Posted Date: July 9th, 2020

DOl: https://doi.org/10.21203/rs.3.rs-38770/v1

License: (9) (1) This work is licensed under a Creative Commons Attribution 4.0 International License. Read Full License 


\section{Abstract}

Background: Squamous cell carcinoma is the most common epithelial tumor of the esophagus. Upper endoscopy with multiple minimally invasive biopsies should be performed to confirm the diagnosis. Leiomyoma of esophagus is rare, but it's the most common benign submucosal mesenchymal tumor of the esophagus. The simultaneous occurrence of an overlying epithelial lesion and a mesenchymal lesion is very rare. This study aims to show a case operated due to squamous cell carcinoma of esophagus that was postoperatively diagnosed with coexistent esophageal leiomyoma and provide a clear overview of the existing literature on it.

Case presentation: The patient was a 41-year-old lady who underwent three field esophagectomy (McKeown). In reviewing the pathology slides, the patient had poorly differentiated squamous cell carcinoma and also multiple leiomyomas. A leiomyoma was coexisted with an invading overlying squamous cell carcinoma.

Conclusion: It is concluded that esophageal carcinomas may coexist with leiomyomas; preexisting benign tumors may have played an important role in the development of carcinoma by inducing constant stimulation of the overlying mucosa; endoscopic ultrasonography is recommended to avoid overestimating the extent of tumor invasion and the resultant aggressive radical surgery; and esophageal resection is still the modality of choice in treatment in developing countries and also countries with limited equipment.

\section{Background:}

Leiomyoma of esophagus is rare, but it's the most common benign submucosal mesenchymal tumor (SMT) of the esophagus; it originates in the smooth muscle cells, and accounts for two-thirds (60-70\%) of all benign esophageal tumors (1-3). It almost appears as a single tumor, and multiple leiomyomas of the esophagus are extremely rare $(1,4)$. Since esophageal leiomyoma is generally a slow-growing tumor and the size of tumor may not change for many years, most affected patients are asymptomatic (2). Often, a diagnosis of esophageal leiomyoma is made as an incidental finding during routine investigation or screening for upper gastrointestinal (GI) pathology (3). Endoscopic ultrasonography (EUS) and computerized tomography (CT) are used for the diagnosis of leiomyoma. The diagnosis is difficult when multiple leiomyomas coexist with carcinoma lesions. In cases where carcinoma overlies a submucosal leiomyoma, there is a possibility of overestimating the extent of tumor invasion, and multiple minute leiomyomas are sometimes misdiagnosed as intramural metastasis (2). Although esophageal leiomyoma is conventionally treated by surgical removal via open thoracotomy for the tumors in the upper two-thirds of the esophagus, minimally invasive approaches like video-assisted thoracoscopic surgery (VATS) and endoscopic resection are other alternative ways used for enucleation of the tumor $(3,5)$.

Squamous cell carcinoma (SCC) is the most common epithelial tumor of the esophagus (2). Upper endoscopy with multiple minimally invasive biopsies should be performed to confirm the diagnosis. Computed tomography of the thorax and abdomen should be performed to evaluate the extent of the primary tumor and search potential liver metastases and celiac lymphadenopathy. An accurate preoperative staging will guide the most appropriate treatment selection. The general treatment recommendations are as follows: Endoscopic resection for superficial, limited mucosa disease (less than T1a), direct surgical resection with lymphadenectomy for lesions penetrating the submucosa with negative lymph nodes (more than T1b), neoadjuvant chemoradiation of resectable lesions invading muscularis propria with positive lymph nodes (less than T2N1), palliative systemic therapy for those locally advanced unresectable or metastatic disease (6).

The simultaneous occurrence of an overlying epithelial lesion (SCC) and a mesenchymal lesion (leiomyoma) is very rare. This study aims to show a case operated due to SCC of esophagus that was postoperatively diagnosed with coexistent esophageal leiomyoma and provide a clear overview of the existing literature on it.

\section{Case Presentation:}

The patient was a 41-year-old lady who was first seen at Shahid Mofateh clinic affiliated to Yasuj University of medical sciences in 2019 with complaints of having progressive dysphagia to solid foods and a ten kilograms weight loss for the preceding 6 months; the patient had also anorexia, decreased intake, and general fatigue and lethargy as accompanying symptoms, but the patient had no nausea and vomiting. In past medical and drug history, the patient had asthma and used fexofenadine and salbutamol spray. There was no family history of malignancy in her parents and siblings. The patient didn't use tobacco, smoke cigarette and drink alcohol. Laboratory values were all within normal limits.

The patient underwent upper GI endoscopy. In esophagus, upper esophageal sphincter, cricopharyngeus and upper third of esophagus were normal. A large fungating and ulcerative mass was found in middle and lower third of esophagus, 25-33 cm from the upper incisors. Z line was normal (Fig. 1). In stomach, cardia (retro-vision maneuver), fundus, body and antrum were normal. In duodenum, bulb and 2nd part were normal. The patient underwent incisional biopsy and was found to have poorly differentiated squamous cell carcinoma in pathology evaluation.

In spiral chest CT scan with and without intravenous (IV) contrast, obtained axial images, represented a $29 * 18 \mathrm{~mm}$ soft tissue fullness at middle to distal esophagus (at the level of carina to the level of main pulmonary artery), which was suggestive for tumoral lesion. No lung metastasis was found. In spiral abdomen and pelvic CT scan with oral and IV contrast, there was a $12 \star 9 \mathrm{~mm}$ lymph node within gastrohepatic ligament (Fig. 2). In abdomen and pelvic sonography, there was a 10*9 mm hypoechoic lesion between left liver lobe and greater curvature which was suggestive of lymphadenopathy (LAP) (Fig. 3.).

The patient received 3 sessions of chemotherapy before undergoing operation. The patient underwent three field esophagectomy (McKeown) including laparotomy, right thoracotomy, and gastric pull-up with cervical anastomosis including extended thoracotomy, esophagectomy, gastric pull-up, pyloroplasty, cervical esophagostomy, jejunostomy, and chest tube insertion. An abdominal lymph node at the gastrohepatic ligament was also resected. The postoperative 
course was uncomplicated. There was no evidence of leak at the anastomotic site by administration of methylene blue dye on the fifth postoperative day and then nasogastric tube was removed and the patient was begun on liquids by mouth. The patient advanced to a regular diet by the tenth postoperative day. She was discharged from the hospital on the 14th day of admission. At a follow-up visit of 1 week and then 2 weeks after discharge from hospital she was feeling well. The patient's condition after surgery came back to her normal habitual life within 3 months. The patient had no complaint at the 9 th month follow-up visit after surgery. Spiral chest and abdomen CT scan was done and showed a pulled-up stomach, filled with fluid and air at the right paraspinal region (Fig. 4).

The specimen was sent in formalin for pathology and immunohistochemistry evaluation. The received specimen was consisted of esophagus and a segment of stomach. Resected esophagus was $12 \mathrm{~cm}$ in length and $3 \mathrm{~cm}$ in greatest diameter. Adventitial surface was congested. On opening, there were four intramural creamy round firm masses measuring from 1 to $2 \mathrm{~cm}$. No perforation site was found. Proximal and distal margins were not grossly involved. The resected segment of stomach was $8 \mathrm{~cm}$ in greater curvature and $6 \mathrm{~cm}$ in lesser curvature and showed no mass (Fig. 5). Multiple lymph nodes were identified measuring from 0.5 to $1 \mathrm{~cm}$ in diameter. In reviewing the slides, the patient had small groups of residual poorly differentiated squamous cell carcinoma and also multiple leiomyomas. A leiomyoma was coexisted with an invading overlying SCC (Fig. 6). There were 5 isolated lymph node within the pathology specimen, of which two were involved with the tumor, but pathology didn't show any sign of metastasis in the lymph node resected at the gastrohepatic ligament. Tumor pathology characteristics are summarized and shown in Table 1.

\section{Discussion:}

There are several reports of co-existing overlying esophageal SCC and leiomyoma in the literature. In this situation, the esophageal submucosal layer is overlaid by the superficial cancer. This coexistence is very rare, and this is usually detected following surgery. Callanan et al, reported the first case of its kind in 1954 (7). In this regard, all previously published reports on cases with leiomyoma overlying with esophageal SCC were searched and found on the web and only available full-text original articles were encountered. As a result, 15 cases in 14 reports were elucidated. These reports were evaluated and summarized in Table 2 according to the originated country and published year of case report, patient's gender, age, chief complaints, risk factors, and comorbid diseases, and upper GI endoscopy, EUS, other diagnostic modalities and pathologic results, location of tumor and treatments applied (1, 2, 4, 8-18).

Of the previous published reports, 10 reports were from Japan, 2 reports were from South Korea, and one report from Iran and Turkey each. It shows that this pathology is much more common in the East Asia, especially in Japan. There was only one female patient previously reported, so our case was the second one. It shows the male predominance pattern in this regard. Ishida et al. reported male to female ratio of 4:1 in patients with SCC overlying leiomyoma (16). Mean age was 59.62 +/- 9.46 years (minimum 41 and maximum 75 years). Our case was the youngest patient in all, as the youngest patient was previously from Turkey with age of 44 years (4).

In chief complains, there were 5 cases with dysphagia or stenotic sensation in the pharyngeal region, 3 cases with significant weight loss, 3 cases with esophageal tumor which were found at the routine health checkups, and one patient with epigastric pain. From the reports in which risk factors were mentioned, heavy smoking was seen in three cases. Comorbid diseases were found negative in 4 cases, and malignant lymphoma of the thyroid and hyperglycemia and osteoporosis were found in one case each. Upper GI endoscopy showed an elevated or protruding lesion in 5 cases, a sessile polypoid lesion in 3 cases, and a submucosal tumor in 3 cases. Chromoendoscopy with iodine staining was done in 7 cases and showed a non-staining area in all. EUS was done in 8 cases and showed a hypoechoic homogeneous submucosal tumor with a well demarcated and clear margin in the muscularis mucosae (MM) covered with intraepithelial layer indicative of leiomyoma in most of the cases. Barium esophagogram study was done in 4 cases. In pathologic evaluation, squamous cell carcinoma in situ (high-grade intraepithelial neoplasia) was seen in 4 cases, poorly differentiated SCC in 2, moderately differentiated SCC in 2 , and malignant SCC in one case. More than one leiomyoma was seen in 3 cases. According to the location of the lesions, proximal, middle and distal third of the esophagus accounted for 5, 6 and 4 cases each retrospectively. Surgery (esophageal resection) was done in 9 cases, and this is comparable with endoscopic submucosal dissection (ESD) which was done in 6 cases.

There are two types of coexistence: 1 . Overlying type in which the carcinoma covers the benign tumor, and 2. the two lesions are completely separated and encountered during or after esophagectomy for esophageal $\operatorname{SCC}(2,12$, and 19). In our case study, the two types exist and this result was as the same as the two other studies done by Iwaya et al. and Geramizadeh et al. $(2,15)$. There are two theories on the etiology of carcinoma development over the leiomyoma: 1. protrusion of leiomyoma into the esophageal lumen and chronic irritation of the esophageal mucosa and predisposing it to dysplasia may be the pathogenesis of the disease; 2 . Underlying leiomyoma prevents the SCC from dissemination and widespread invasion $(2,13$, and 15$)$.

An upper GI endoscopy is usually used for the differential diagnosis of esophageal carcinoma and leiomyoma, but it may not always lead to an accurate diagnosis, because esophageal leiomyomas are submucosal lesions. Availability of EUS provides an advantage in the detection and management of these tumors as it clearly reveals the five-layered structure of the gastrointestinal wall as well as by enabling exact localization and origin, tumor margin, echogenic pattern, and accurate size measurement $(4,5)$; but unfortunately we didn't have EUS in our hospital, so we were unaware about coexistence of any leiomyoma until it had been removed through esophagectomy.

Narrow band imaging (NBI) endoscopy uses optical filters that improve absorbance and scattering of light, enhancing the appearance of vessels and other structures, thus providing a high contrast of tissue surface during endoscopy. Along with magnifying endoscopes and chromoendoscopy, a close to histological tissue description is possible. These have been used to improve the assessment of esophageal lesions (5); but unfortunately we did not have any of these to help evaluate the tumor or esophageal mucosa.

When choosing treatment for SMT, it is important to determine by endoscopic ultrasonography from which layer the tumor originates. If a small SMT is diagnosed as originating from the muscularis mucosa, endoscopic submucosal resection (EMR) is the treatment of choice. When the tumors are large and 
originate in the muscularis propria, this technique has the risk of severe complications, such as esophageal perforation and massive bleeding. Hence, in those cases, open surgery or thoracoscopic resection is chosen. In this case, as we didn't have EUS and EMR, so open surgery was performed.

\section{Conclusion:}

To sum up it can be concluded that 1. it must kept in mind that esophageal carcinomas may coexist with leiomyomas, 2. preexisting benign tumors may have played an important role in the development of carcinoma by inducing constant stimulation of the overlying mucosa, 3 . EUS is recommended to avoid overestimating the extent of tumor invasion and the resultant aggressive radical surgery 4 . Esophageal resection is still the modality of choice in treatment in developing countries and also countries with limited equipment.

\section{Abbreviations:}

Submucosal mesenchymal tumor (SMT)

Endoscopic ultrasonography (EUS)

Computerized tomography (CT)

Gastrointestinal (GI)

Video-assisted thoracoscopic surgery (VATS)

Squamous cell carcinoma (SCC)

Intravenous (IV)

Muscularis mucosae (MM)

Endoscopic submucosal dissection (ESD)

Endoscopic submucosal resection (EMR)

Narrow band imaging (NBI) endoscopy

\section{Declarations}

\section{Ethics approval and consent to participate}

Written informed consent was obtained from the patient for participation. A copy of the written consent is available for review by the Editor-in-Chief of this journal.

\section{Consent for publication}

Written informed consent was obtained from the patient for publication of this case report and any accompanying images. A copy of the written consent is available for review by the Editor-in-Chief of this journal.

\section{Availability of data and materials}

The datasets used and/or analysed during the current study are available from the corresponding author on reasonable request.

\section{Competing interests}

The authors of this manuscript declare no competing of interests

\section{Funding}

Not received.

\section{Acknowledgment}

We all express our gratitude to the patient who kindly gave consent for this case to be presented in this paper. The authors also wish to thank Dr. Aida Iraji at the Central research laboratory, Shiraz University of Medical Sciences, Shiraz, Iran for her assistance in editing this manuscript. 


\section{Contributions}

Principal author: SM evaluated the patient clinically, operated the patient (main surgeon), read and revised the paper.

Corresponding-author: MJYB evaluated the patient clinically, helped to operate the patient (co-surgeon), prepared the first draft and revised the paper.

Co-author: SH evaluated the pathology slides (our pathologist and revised the manuscript.

Co-author: HS helped in collecting the patient data, assisted with the administration and monitoring of anesthesia during patients operation and upper GI endoscopy (our anesthetic technician).

All authors read and approved the final manuscript.

\section{References}

1. Seo M, Kim DH, Cho YW, et al. Superficial Esophageal Neoplasms Overlying Leiomyomas Removed by Endoscopic Submucosal Dissection: Case Reports and Review of the Literature. Clin Endosc. 2015; 48(4):322- https://doi:10.5946/ce.2015.48.4.322

2. Iwaya T, Maesawa C, Uesugi N, et al. Coexistence of esophageal superficial carcinoma and multiple leiomyomas: A case report. World J Gastroenterol. 2006; 12(28):4588- https://doi:10.3748/wjg.v12.i28.4588

3. Mathew G, Carter YM. Esophageal Leiomyoma. [Updated 2019 Aug 3]. In: StatPearls [Internet]. Treasure Island (FL): StatPearls Publishing; 2020 Jan-. Available from: https://www.ncbi.nlm.nih.gov/books/NBK459298/

4. Erol M. Coexistence of esophageal squamous cell carcinoma and leiomyoma: a case report. Turkish Journal of Thoracic and Cardiovascular Surgery. 2012; 20: 944-946. https://doi:10.5606/tgkdc.dergisi.2012.188

5. Ismaila BO, Davwar PM. Endoscopic resection of an esophageal leiomyoma with overlying dysplasia without specialized equipment. Niger J Clin Pract. 2016; 19(3):418- https://doi:10.4103/1119-3077.179294

6. Recio-Boiles A, Waheed A, Babiker HM. Cancer, Esophageal. [Updated 2019 Aug 4]. In: StatPearls [Internet]. Treasure Island (FL): StatPearls Publishing; 2020 Jan-. Available from: https://www.ncbi.nlm.nih.gov/books/NBK459267/

7. Callanan JG. Simultaneous occurrence of simple and malignant tumors in the esophagus. J Thorac Surg. 1954; 28(1):4-10.

8. lizuka T, Kato H, Watanabe H, Itabashi M, Hirota T. Superficial carcinoma of the esophagus coexisting with esophageal leiomyoma: a case report and review of the Japanese literature. Jpn J Clin Oncol. 1984; 14(1):115- https://doi:10.1093/oxfordjournals.jjco.a038944

9. Kuwano H, Sadanaga N, Watanabe M, Yasuda M, Nozoe T, Sugimachi K. Esophageal squamous cell carcinoma occurring in the surface epithelium over a benign tumor. J Surg Oncol. 1995; 59(4):268- https://doi:10.1002/jso.2930590414

10. Yoshikane H, Tsukamoto Y, Niwa Y, et al. The coexistence of esophageal submucosal tumor and carcinoma. Endoscopy. 1995; 27(1):119https://doi:10.1055/s-2007-1005645

11. Nagashima R, Takeda H, Motoyama T, Tsukamoto O, Takahashi T. Coexistence of superficial esophageal carcinoma and leiomyoma: case report of an endoscopic resection. Endoscopy. 1997; 29(7):683- https://doi:10.1055/s-2007-1004280

12. Fu Kl, Muto M, Mera K, et al. Carcinoma coexisting with esophageal leiomyoma. Gastrointest Endosc. 2002; 56(2):272- https://doi:10.1016/s00165107(02)70191-0

13. Mizobuchi S, Kuge K, Matsumoto Y, et al. Co-existence of early esophageal carcinoma and leiomyoma: a case report. Jpn J Clin Oncol. 2004; 34(12):751https://doi:10.1093/jjco/hyh133

14. Ishihara R, Yamamoto S, Yamamoto S, et al. Endoscopic resection of the esophageal squamous cell carcinoma overlying leiomyoma. Gastrointest Endosc. 2008; 67(4):745- https://doi:10.1016/j.gie.2007.09.021

15. Geramizadeh B, Ziyaian B, Safari A. Invasion of esophageal leiomyoma by coexistent overlying squamous cell carcinoma. J Gastrointest Cancer. 2009; 40(3-4):131- https://doi:10.1007/s12029-009-9093-8

16. Niimi K, Kodashima S, Ono S, Goto O, Yamamichi N, Fujishiro M. Curative ESD for intraepithelial esophageal carcinoma with leiomyoma mimicking submucosal invasive carcinoma. World J Gastrointest Endosc. 2009; 1(1):68- https://doi:10.4253/wjge.v1.i1.68

17. Ishida M, Mochizuki Y, Iwai M, Yoshida K, Kagotani A, Okabe H. Esophageal squamous cell carcinoma in situ overlying leiomyoma: a case report with review of the literature. Int J Clin Exp Pathol. 2013; 6(12):3026-

18. Oh WJ, Lee EJ, Lee YS, Kim TJ. Esophageal squamous cell carcinoma in situ overlying leiomyoma mimicking invasive cancer: a brief case report. Korean J Pathol. 2014; 48(2):162- https://doi:10.4132/KoreanJPathol.2014.48.2.162

19. Lu YK, Li YM, Keng CC. The coexistence of benign and malignant tumors of the esophagus. Chin Med J. 1963; 82:805-808.

\section{Tables}


Table 1. Tumor pathology and immunohistochemistry characteristics

\begin{tabular}{|c|c|}
\hline Tumor type & SCC, poorly differentiated (G3) \\
\hline Residual tumor size & $0.6 \mathrm{~cm}$ \\
\hline Tumor extension & Tumor invaded submucosal (at least) \\
\hline Proximal margin & Free of tumor \\
\hline Distal margin & Free of tumor \\
\hline Radial margin & Free of tumor \\
\hline Treatment effect & Near complete response, score 1 (single cell and small groups of cancer cells \\
\hline $\begin{array}{l}\text { Lymphovascular } \\
\text { invasion }\end{array}$ & Present \\
\hline Perineural invasion & Present \\
\hline Lymph-node invasion & Total: 5, involved: 2; metastatic poorly differentiated squamous cell carcinoma (LN2) \\
\hline $\begin{array}{l}\text { Additional pathologic } \\
\text { findings }\end{array}$ & Multiple leiomyomas, the largest one measuring: $2 \mathrm{~cm}$ in diameter \\
\hline Pathologic staging & ypT1bN1Mx \\
\hline \multirow[t]{2}{*}{ Immunohistochemistry } & Negative for C-KIT and CDX2 proto-oncogenes \\
\hline & Positive for Desmin and P63 proto-oncogenes \\
\hline Note & $\begin{array}{l}\text { This staging categorizes the extent of tumor actually present at the time of examination (after the chemotherapy). The " } y \text { " } \\
\text { categorization is not an estimate of tumor before chemotherapy. }\end{array}$ \\
\hline
\end{tabular}


Table 2. Summarized previous published reports on leiomyoma with overlying SCC

\begin{tabular}{|c|c|c|c|c|c|c|c|c|}
\hline $\begin{array}{l}\text { Country } \\
\text { and } \\
\text { year }\end{array}$ & $\begin{array}{l}\text { Gender } \\
\text { and age }\end{array}$ & $\begin{array}{l}\text { Chief } \\
\text { complaints }\end{array}$ & Risk factors & $\begin{array}{l}\text { Comorbid } \\
\text { diseases }\end{array}$ & $\begin{array}{l}\text { Upper GI } \\
\text { Endoscopy }\end{array}$ & EUS & $\begin{array}{l}\text { Other diagnostic } \\
\text { modalities (1) }\end{array}$ & $\begin{array}{l}\text { Other diagnostic } \\
\text { modalities (2) }\end{array}$ \\
\hline $\begin{array}{l}\text { Japan, } \\
1984 \\
(8)\end{array}$ & Male/ 75 & $\begin{array}{l}\text { Stenotic } \\
\text { sensation in } \\
\text { the } \\
\text { pharyngeal } \\
\text { region }\end{array}$ & $\begin{array}{l}\text { Heavy } \\
\text { smoking }\end{array}$ & & $\begin{array}{l}\text { An elevated } \\
\text { erosive } \\
\text { lesion in the } \\
\text { posterior } \\
\text { wall of the } \\
\text { esophagus }\end{array}$ & & $\begin{array}{l}\text { Barium } \\
\text { esophagogram: a } \\
\text { tumorous } \\
\text { shadow, } 5 \mathrm{~cm} \text {, } \\
\text { middle thoracic } \\
\text { esophagus }\end{array}$ & \\
\hline $\begin{array}{l}\text { Japan, } \\
1995 \\
(9)\end{array}$ & Male/45 & Dysphagia & & & & & & \\
\hline $\begin{array}{l}\text { Japan, } \\
\text { 1995 } \\
(9)\end{array}$ & Male/71 & $\begin{array}{l}\text { Not } \\
\text { mentioned, } \\
\text { referred for } \\
\text { treatment of } \\
\text { an } \\
\text { esophageal } \\
\text { tumor }\end{array}$ & & & $\begin{array}{l}\text { A mucosal } \\
\text { irregularity } \\
\text { on the } \\
\text { surface of } \\
\text { the } \\
\text { submucosal } \\
\text { tumor }\end{array}$ & & & \\
\hline $\begin{array}{l}\text { Japan, } \\
1995 \\
(10)\end{array}$ & Male/52 & Asymptomatic & $\begin{array}{l}\text { Heavy } \\
\text { smoking }\end{array}$ & Negative & $\begin{array}{l}\text { Sessile } \\
\text { polypoid } \\
\text { lesion at } \\
\text { abdominal } \\
\text { esophagus }\end{array}$ & $\begin{array}{l}\text { A 9mm } \\
\text { submucosal } \\
\text { tumor with } \\
\text { smooth } \\
\text { contour, } \\
\text { leiomyoma }\end{array}$ & $\begin{array}{l}\text { Barium swallow: } \\
\text { as health checkup }\end{array}$ & $\begin{array}{l}\text { Double contrast } \\
\text { barium } \\
\text { esophagogram: } \\
\text { semispherical } \\
\text { tumor, } 1.5 \mathrm{~cm}\end{array}$ \\
\hline $\begin{array}{l}\text { Japan, } \\
1997 \\
(11)\end{array}$ & Male/61 & & & & $\begin{array}{l}\text { Sessile } \\
\text { polypoid } \\
\text { lesion with } \\
\text { a smooth } \\
\text { surface at } \\
\text { the } \\
\text { esophagus }\end{array}$ & $\begin{array}{l}\text { A hypoechoic } \\
\text { tumor just } \\
\text { below the } \\
\text { epithelial } \\
\text { layer }\end{array}$ & & \\
\hline $\begin{array}{l}\text { Japan, } \\
2002 \\
(12)\end{array}$ & Male/62 & $\begin{array}{l}\text { Not } \\
\text { mentioned, } \\
\text { referred for } \\
\text { treatment of } \\
\text { an } \\
\text { esophageal } \\
\text { tumor }\end{array}$ & & & $\begin{array}{l}\text { A protruding } \\
\text { lesion, } \\
\text { resembling } \\
\text { a } \\
\text { submucosal } \\
\text { tumor, in the } \\
\text { proximal } \\
\text { third of the } \\
\text { esophagus }\end{array}$ & $\begin{array}{l}\text { A hypoechoic } \\
\text { tumor } \\
\text { confined to } \\
\text { the } \\
\text { submucosa } \\
\text { with a well } \\
\text { demarcated, } \\
\text { smooth } \\
\text { outline }\end{array}$ & $\begin{array}{l}\text { Chromoendoscopy: } \\
\text { non-staining }\end{array}$ & \\
\hline $\begin{array}{l}\text { Japan, } \\
2004 \\
(13)\end{array}$ & Male/65 & & & & $\begin{array}{l}\text { A sessile } \\
\text { polypoid } \\
\text { lesion with } \\
\text { a smooth } \\
\text { surface in } \\
\text { the } \\
\text { proximal } \\
\text { third of the } \\
\text { esophagus }\end{array}$ & $\begin{array}{l}\text { A hypoechoic } \\
\text { tumor, } 13 \mathrm{~mm} \\
\text { in diameter, } \\
\text { located in the } \\
\text { submucosa, } \\
\text { with clear } \\
\text { margins and } \\
\text { a smooth } \\
\text { contour, with } \\
\text { the } \\
\text { muscularis } \\
\text { propria layer } \\
\text { intact }\end{array}$ & $\begin{array}{l}\text { Chromoendoscopy: } \\
\text { non-staining }\end{array}$ & \\
\hline $\begin{array}{l}\text { Japan, } \\
2006 \\
(2)\end{array}$ & Male/71 & & & $\begin{array}{l}\text { malignant } \\
\text { lymphoma of } \\
\text { the thyroid }\end{array}$ & $\begin{array}{l}\text { A superficial } \\
\text { ulcerative } \\
\text { tumor ( } 24 \\
\mathrm{~mm} \text { in } \\
\text { diameter) in } \\
\text { the } \\
\text { lower third } \\
\text { of the } \\
\text { esophagus, } \\
\text { overlying } \\
\text { the smaller } \\
\text { leiomyoma }\end{array}$ & $\begin{array}{l}\text { Cancer } \\
\text { overlaid the } \\
\text { smaller } \\
\text { leiomyoma } \\
\text { and invaded } \\
\text { the } \\
\text { submucosal } \\
\text { layer }\end{array}$ & $\begin{array}{l}\text { Barium swallow } \\
\text { Esophagogram: } \\
\text { two smoothly } \\
\text { rounded defects }\end{array}$ & $\begin{array}{l}\text { Chromoendoscopy: } \\
\text { non-staining }\end{array}$ \\
\hline \multirow[t]{2}{*}{$\begin{array}{l}\text { Japan, } \\
2008 \\
(14)\end{array}$} & Male/61 & $\begin{array}{l}\text { Mild } \\
\text { epigastralgia }\end{array}$ & & & $\begin{array}{l}\text { A } \\
\text { submucosal } \\
\text { tumor with } \\
\text { a smooth } \\
\text { and mildly }\end{array}$ & $\begin{array}{l}\text { A hypoechoic } \\
\text { lesion } \\
\text { originating } \\
\text { from the }\end{array}$ & $\begin{array}{l}\text { Chromoendoscopy } \\
\text { with iodine } \\
\text { staining: non- } \\
\text { staining area }\end{array}$ & \\
\hline & \multicolumn{8}{|c|}{ Page $7 / 12$} \\
\hline
\end{tabular}




\begin{tabular}{|c|c|c|c|c|c|c|c|c|}
\hline & & & & & $\begin{array}{l}\text { red surface } \\
\text { mucosa in } \\
\text { the } \\
\text { proximal } \\
\text { third of the } \\
\text { esophagus }\end{array}$ & $\begin{array}{l}\text { muscularis } \\
\text { mucosae with } \\
\text { a clear margin }\end{array}$ & & \\
\hline $\begin{array}{l}\text { Iran, } \\
2009 \\
(15)\end{array}$ & Male/47 & $\begin{array}{l}\text { Progressive } \\
\text { dysphagia } \\
\text { and epigastric } \\
\text { pain and } \\
\text { about } 20 \mathrm{~kg} \\
\text { weight loss. }\end{array}$ & & & $\begin{array}{l}\text { A depressed } \\
\text { area with } \\
\text { uneven and } \\
\text { irregular } \\
\text { border }\end{array}$ & & & \\
\hline $\begin{array}{l}\text { Japan, } \\
2009 \\
(16)\end{array}$ & Male/65 & Asymptomatic & $\begin{array}{l}\text { Heavy } \\
\text { smoking and } \\
\text { alcohol } \\
\text { consumption }\end{array}$ & Negative & $\begin{array}{l}\text { An } \\
\text { esophageal } \\
\text { tumor in the } \\
\text { middle } \\
\text { thoracic } \\
\text { esophagus }\end{array}$ & $\begin{array}{l}\text { Hypoechoic } \\
\text { tumor in the } \\
\text { muscularis } \\
\text { mucosae } \\
\text { covered with } \\
\text { intraepithelial } \\
\text { layer } \\
\text { indicative of } \\
\text { leiomyoma }\end{array}$ & $\begin{array}{l}\text { Chromoendoscopy } \\
\text { with iodine } \\
\text { staining: non- } \\
\text { staining area }\end{array}$ & $\begin{array}{l}\text { Magnifying } \\
\text { endoscopy with } \\
\text { narrow band } \\
\text { imaging (NBI): } \\
\text { dilated and } \\
\text { elongated } \\
\text { intrapapillary } \\
\text { capillary loop } \\
\text { (IPCL), indicated } \\
\text { intraepithelial } \\
\text { carcinoma }\end{array}$ \\
\hline $\begin{array}{l}\text { Turkey } \\
2012 \\
(4)\end{array}$ & Male/44 & $\begin{array}{l}\text { Weight loss } \\
\text { and } \\
\text { dysphagia } \\
\text { for two } \\
\text { month }\end{array}$ & Negative & Negative & $\begin{array}{l}\text { A tumoral } \\
\text { mass with } \\
\text { a partially } \\
\text { irregular } \\
\text { surface in } \\
\text { the distal } \\
\text { third of the } \\
\text { esophagus }\end{array}$ & & $\begin{array}{l}\text { CT scan of the } \\
\text { thorax and } \\
\text { abdomen: } \\
\text { minimally diffuse } \\
\text { esophageal wall } \\
\text { enlargement } \\
\text { in a } 5 \mathrm{~cm} \text { segment } \\
\text { of the distal } \\
\text { esophagus with no } \\
\text { lymph } \\
\text { node involvement } \\
\text { or distant } \\
\text { metastasis }\end{array}$ & \\
\hline $\begin{array}{l}\text { Japan, } \\
2013 \\
(17)\end{array}$ & Female/75 & $\begin{array}{l}\text { Esophageal } \\
\text { tumor at } \\
\text { health } \\
\text { checkup }\end{array}$ & & $\begin{array}{l}\text { hyperglycemia } \\
\text { and } \\
\text { osteoporosis }\end{array}$ & $\begin{array}{l}\text { A } \\
\text { submucosal } \\
\text { tumor, } \\
\text { measuring } \\
5 \times 4 \text { mm in } \\
\text { diameter, } 20 \\
\text { cm from the } \\
\text { incisors }\end{array}$ & & & \\
\hline $\begin{array}{l}\text { South } \\
\text { Korea, } \\
2014 \\
(18)\end{array}$ & Male/53 & $\begin{array}{l}\text { Esophageal } \\
\text { tumor at } \\
\text { health } \\
\text { checkup }\end{array}$ & & & $\begin{array}{l}\text { An elevated } \\
\text { mass, } 1.8 \\
\text { cm in } \\
\text { diameter, } \\
\text { with } \\
\text { irregular } \\
\text { central } \\
\text { small } \\
\text { erosion in } \\
\text { the upper } \\
\text { thoracic } \\
\text { esophagus. }\end{array}$ & & $\begin{array}{l}\text { Chromoendoscopy } \\
\text { with iodine } \\
\text { staining: non- } \\
\text { staining area }\end{array}$ & \\
\hline $\begin{array}{l}\text { South } \\
\text { Korea, } \\
2015 \\
(1)\end{array}$ & Male/66 & $\begin{array}{l}\text { Esophageal } \\
\text { tumor at } \\
\text { health } \\
\text { checkup }\end{array}$ & & & $\begin{array}{l}\text { A protruding } \\
\text { mass that } \\
\text { measured } \\
1 \times 1 \mathrm{~cm} \text { in } \\
\text { diameter } \\
\text { and was } \\
\text { located } 25 \\
\mathrm{~cm} \text { from the } \\
\text { upper } \\
\text { incisors. }\end{array}$ & $\begin{array}{l}\text { A hypoechoic } \\
\text { and } \\
\text { homogeneous } \\
\text { lesion that } \\
\text { originated } \\
\text { from the } \\
\text { muscularis } \\
\text { mucosa (MM) } \\
\text { below the } \\
\text { epithelial } \\
\text { layer. }\end{array}$ & $\begin{array}{l}\text { Chromoendoscopy } \\
\text { with iodine } \\
\text { staining: non- } \\
\text { staining area }\end{array}$ & \\
\hline $\begin{array}{l}\text { Iran, } \\
2020\end{array}$ & Female/41 & $\begin{array}{l}\text { Progressive } \\
\text { dysphagia } \\
\text { and } \\
\text { significant } \\
\text { weight loss } \\
\text { for the } \\
\text { preceding } 6 \\
\text { months }\end{array}$ & Negative & Negative & $\begin{array}{l}\text { A large } \\
\text { fungating } \\
\text { and } \\
\text { ulcerative } \\
\text { mass, } \\
\text { middle and } \\
\text { lower third } \\
\text { of }\end{array}$ & & $\begin{array}{l}\text { Chest CT scan: a } \\
29 * 18 \text { mm soft } \\
\text { tissue fullness at } \\
\text { middle to distal } \\
\text { esophagus, } \\
\text { suggestive for } \\
\text { tumoral lesion. }\end{array}$ & \\
\hline
\end{tabular}




\section{Figures}

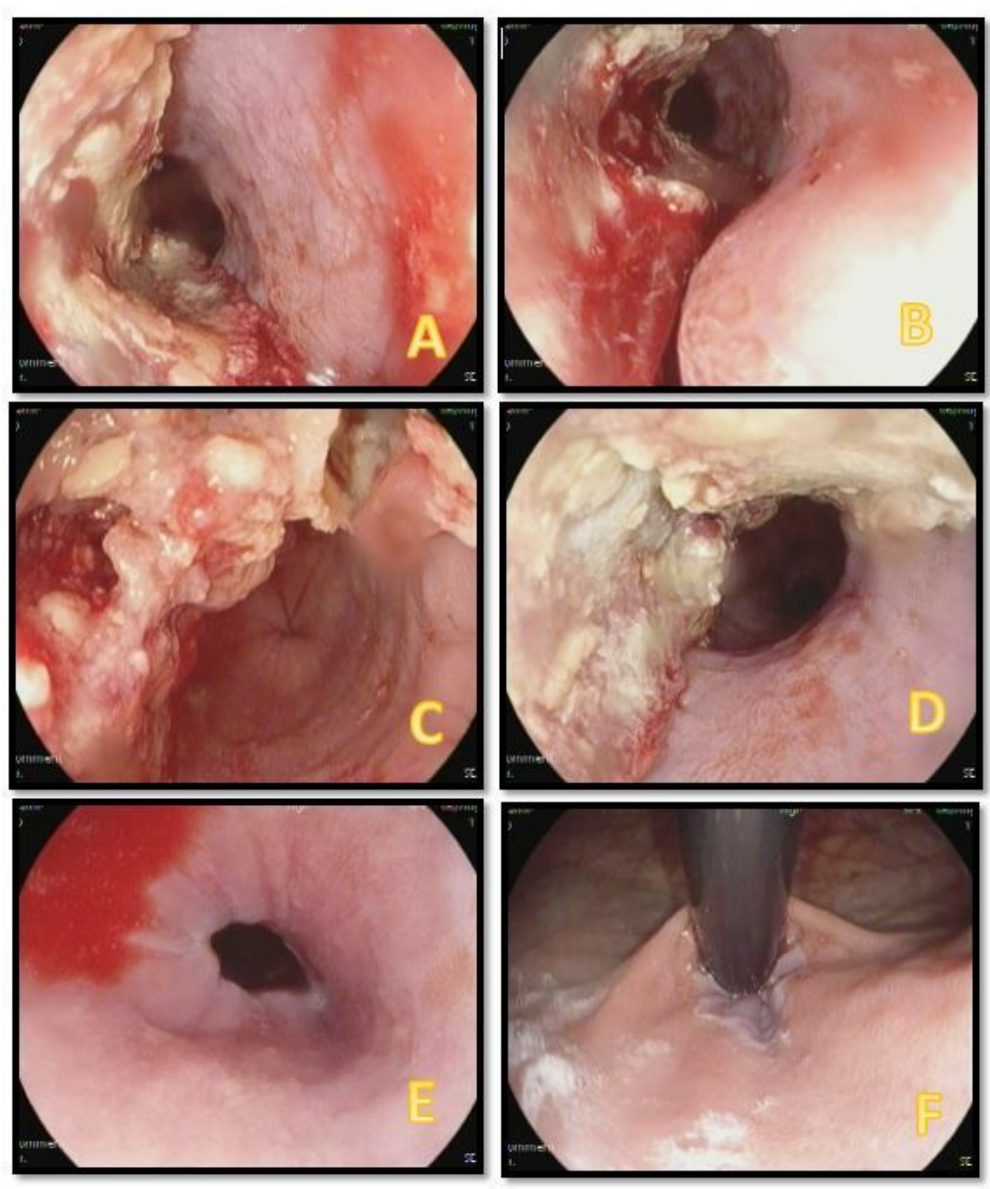

Figure 1

Upper GI endoscopy: large fungating and ulcerative mass in middle (A and B) and lower third (C and D) of esophagus, Z-line (E), Cardia (F) 

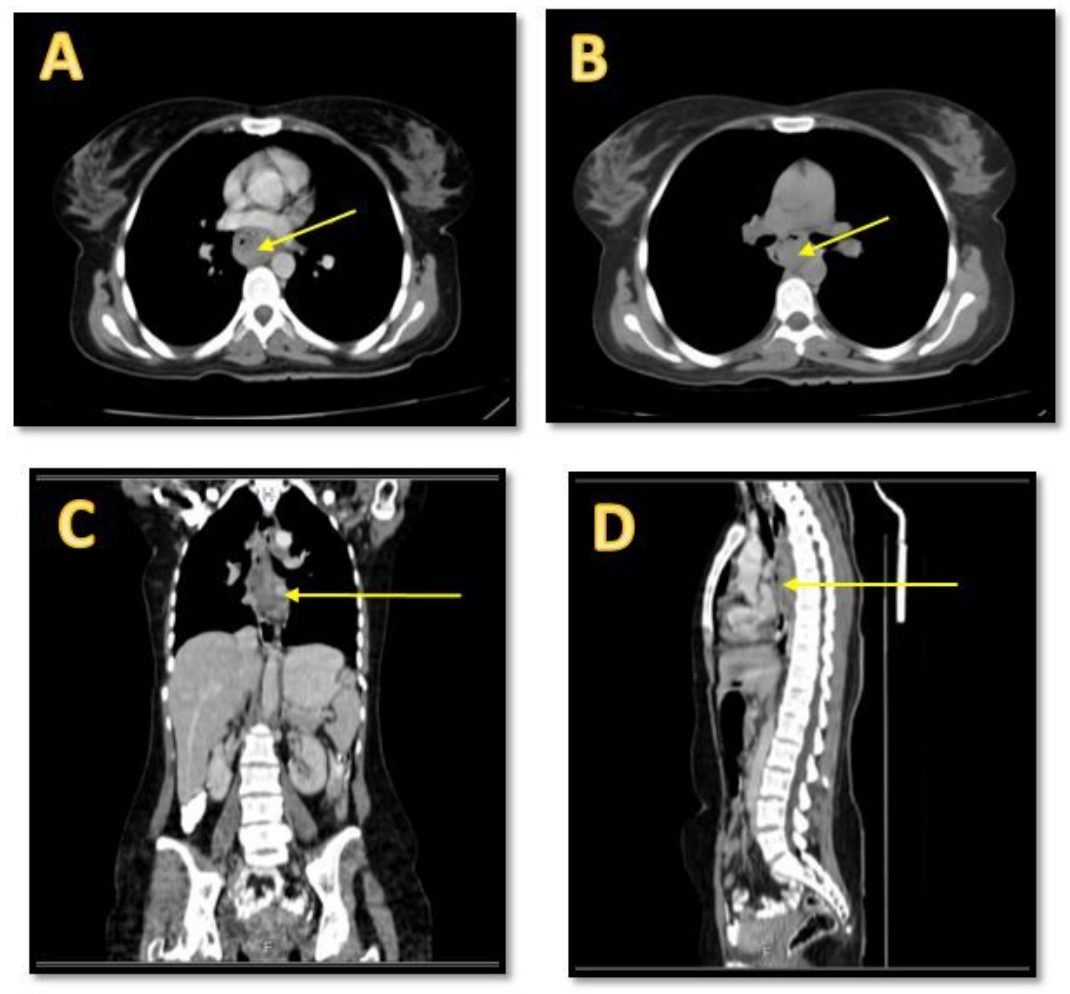

\section{Figure 2}

Spiral chest CT scan with and IV contrast (yellow arrows show the tumor); A: Axial view with IV contrast; B: Axial view without contrast; C: Coronal view with IV contrast; D: Sagittal View with IV contrast

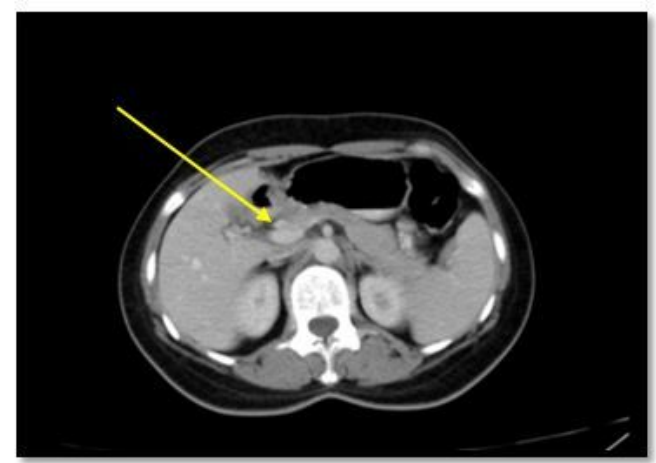

\section{Figure 3}

Spiral abdomen and pelvic CT scan: a lymph node within gastrohepatic ligament shown with yellow arrow 


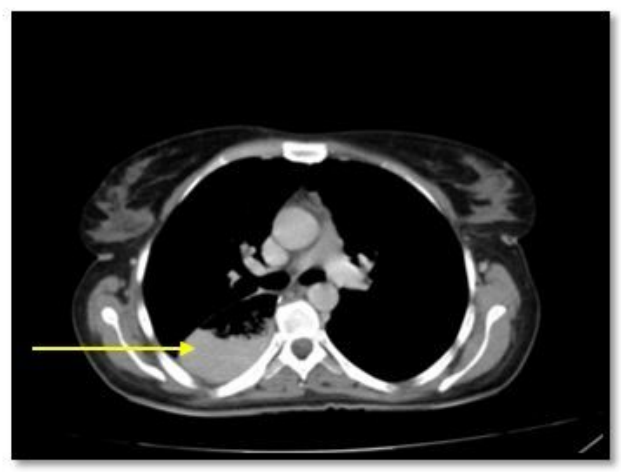

Figure 4

Spiral chest CT scan: pulled-up stomach at the right paraspinal region shown in yellow arrow.
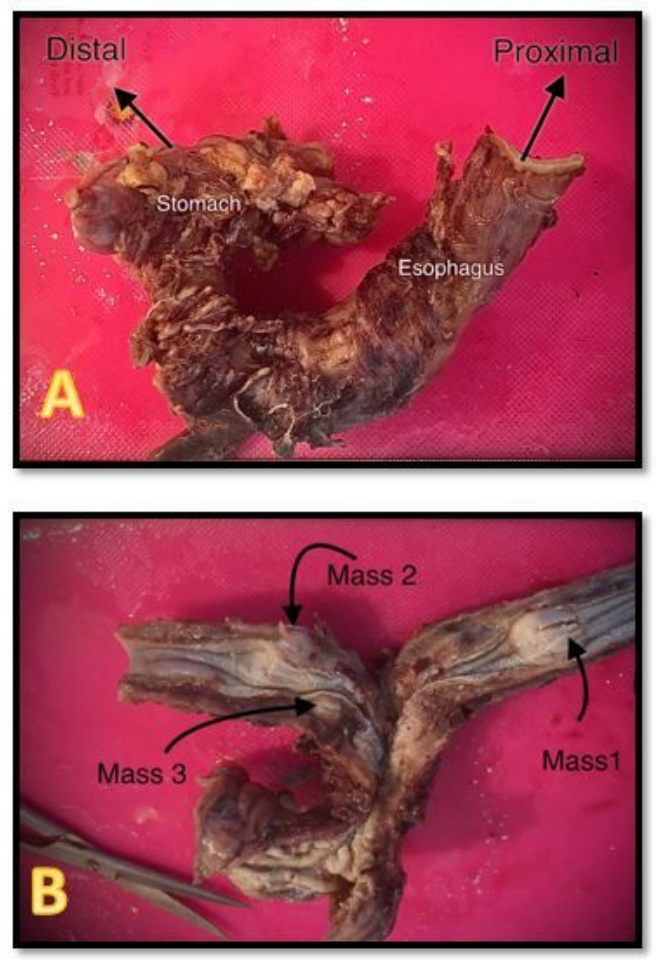

\section{Figure 5}

A. Gross Pathology of the specimen, B. Three Three leiomyomas in gross pathology of the specimen 

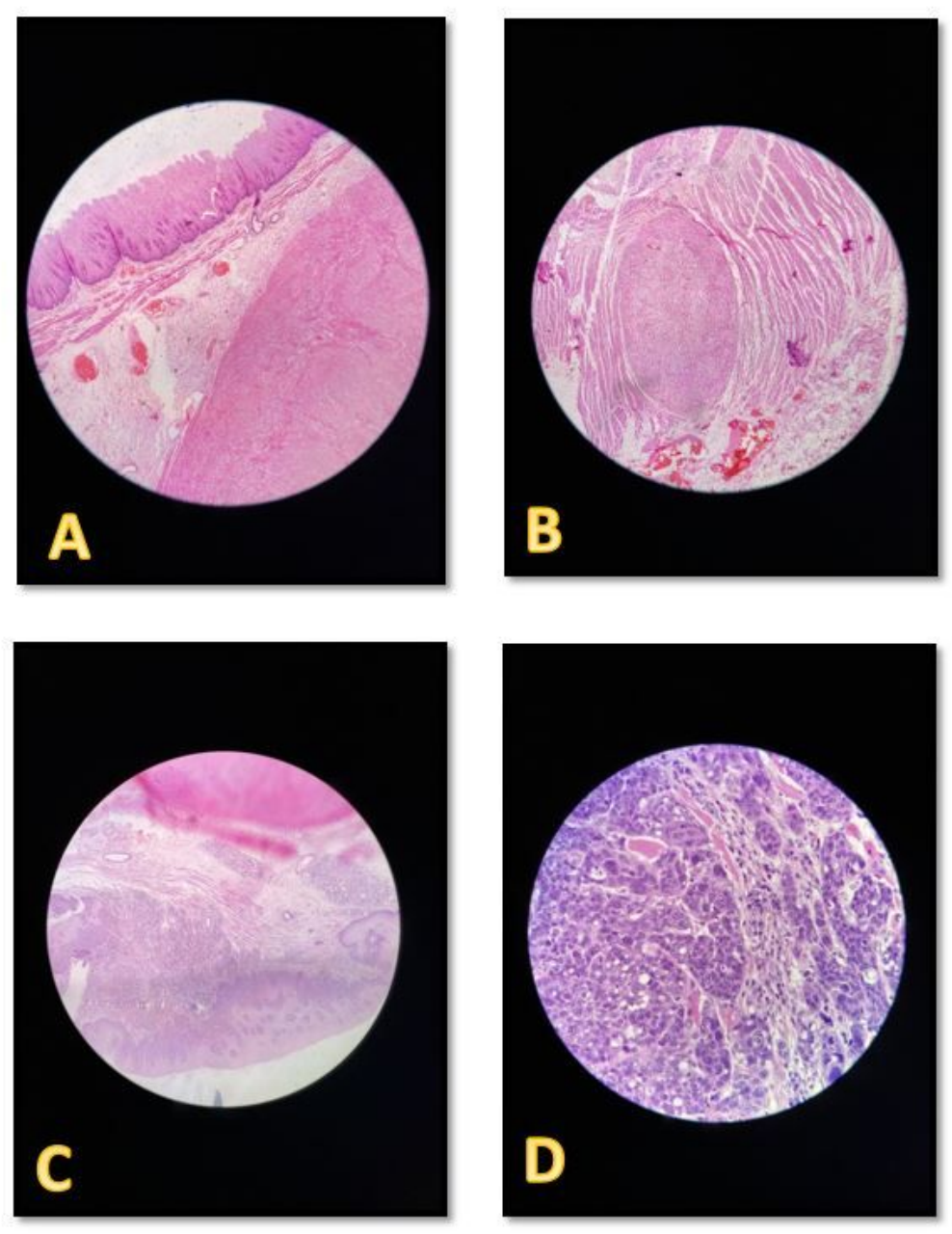

\section{Figure 6}

A. A leiomyoma with normal overlying epithelium, B. A small separated leiomyoma, C. Overlying submucosal SCC on a leiomyoma, D. SCC residual tumor cell nests 